\title{
For a better landing
}

\author{
Osami Honjo, $\mathrm{MD}, \mathrm{PhD},{ }^{\mathrm{a}, \mathrm{b}}$ and Shuhua Luo, $\mathrm{MD}, \mathrm{PhD}^{\mathrm{a}, \mathrm{b}, \mathrm{c}}$
}

\footnotetext{
From the a Division of Cardiovascular Surgery, Labatt Family Heart Centre, The Hospital for Sick Children, Toronto, Ontario, Canada; ${ }^{\mathrm{b}}$ Department of Surgery, University of Toronto, Toronto, Ontario, Canada; and ${ }^{\mathrm{c} D e p a r t-}$ ment of Cardiovascular Surgery, West China Hospital of Sichuan University, Chengdu, China.

Disclosures: Authors have nothing to disclose with regard to commercial support.

Received for publication Oct 17, 2017; accepted for publication Oct 30, 2017; available ahead of print Dec 7, 2017.

Address for reprints: Osami Honjo, MD, PhD, Division of Cardiovascular Surgery, Labatt Family Heart Center, The Hospital for Sick Children, 555 University Ave, Toronto, Ontario, Canada M5G1X8 (E-mail: osami. honjo@sickkids.ca).

J Thorac Cardiovasc Surg 2018;155:744-5

$0022-5223 / \$ 36.00$

Copyright (c) 2017 by The American Association for Thoracic Surgery

https://doi.org/10.1016/j.jtcvs.2017.10.110
}

A high proportion of the patients with tetralogy of Fallot who previously underwent corrective surgery require pulmonary valve replacement (PVR) due to significant pulmonary insufficiency and progressive right ventricular dilatation. Percutaneous PVR using a Melody valve (Medtronic Inc, Minneapolic, Minnesota) has been increasingly used with excellent medium-term freedom from reintervention. ${ }^{1,2}$ However, there are some anatomic contraindications for percutaneous Melody valve implantation, such as markedly dilated right ventricular outflow tract (RVOT) with no waist to anchor the valve, and an implanted tissue valve with an unfavorable angulation. Trezzi and colleagues ${ }^{3}$ report an innovative surgical technique of PVR for patients with postrepair tetralogy of Fallot with pulmonary insufficiency. ${ }^{3}$ The technique was particularly designed to overcome 2 major above-mentioned contraindication for future percutaneous PVR. The polytetrafluoroethylene (PTFE) graft was used for 2 purposes: to reduce the size of the RVOT, and to provide a cylindrical RVOT geometry that is a suitable landing site for future of this technique.

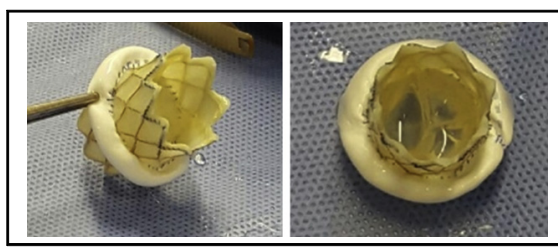

Melody valve (Medtronic Inc, Minneapolic, Minnesota).

\section{Central Message}

Surgical technique for placement of the Melody valve (Medtronic Inc, Minneapolic, Minnesota) in dilated right ventricular outflow tract.

See Article page 739.

percutaneous PVR. The initial experience of 8 patients appears to be promising. In addition to 2 major advantages, relatively straightforward surgical technique required and reproducibility would be further benefits

Whether this technique with a Melody valve brings a better long-term outcome regarding valve durability and reintervention rate is yet to be determined. Although mediumterm valve competency of the Melody valve up to 7 years is excellent, ${ }^{2}$ we still have to see how this valve works 10 to 15 years after implantation. There is a concern of infectious endocarditis after Melody valve implantation: $4.3 \%$ in 1 series, and $89 \%$ freedom from infectious endocarditis at 5 years in the other series. ${ }^{1,2}$ These numbers are somewhat higher than those with a tissue valve in the
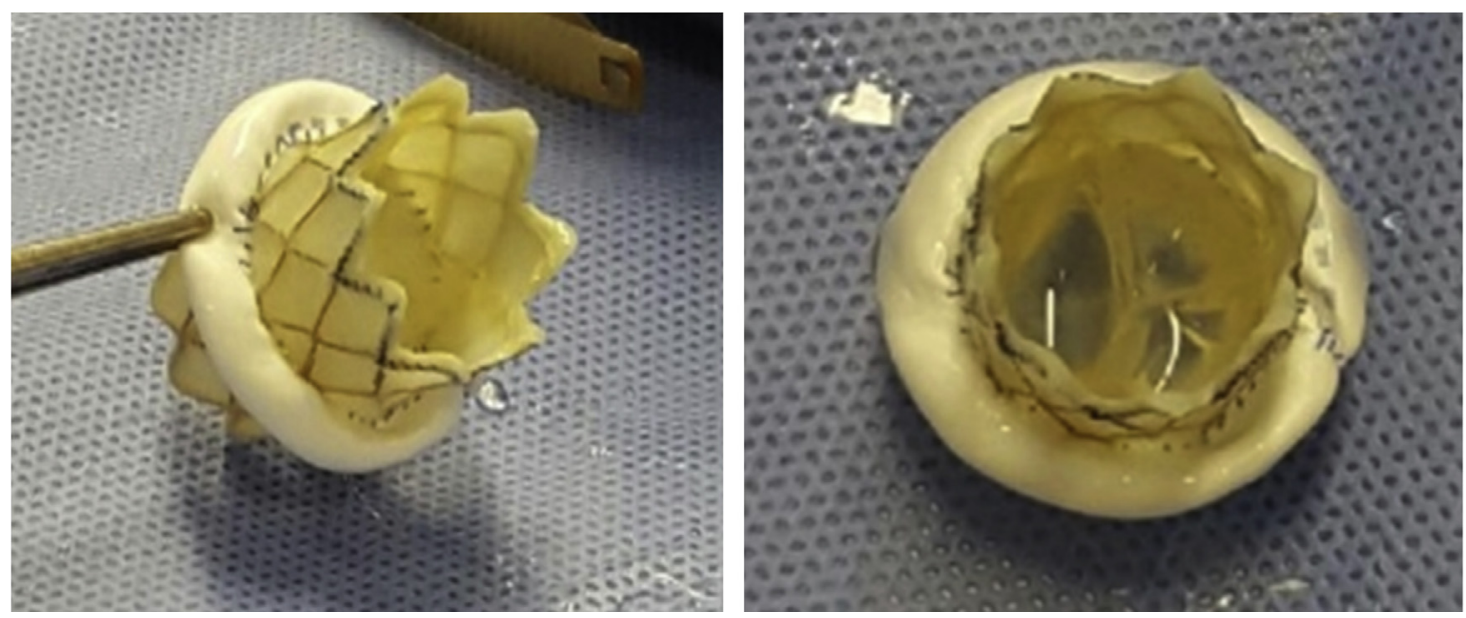

FIGURE 1. Melody valve with a PTFE sewing cuff (Medtronic Inc, Minneapolic, Minnesota). 
pulmonary valve position among tetralogy cohort, which ranges from $0 \%$ to $3.5 \%{ }^{4,5}$ With an extra PTFE graft in situ, infectious endocarditis risk has to be determined in the subsequent follow-up studies.

We have recently performed PVR in a patient aged 2.5 years who had undergone tetralogy of Fallot and had a hugely dilated RVOT and right ventricle at 2 years following the corrective surgery. Based on our experience with Melody valve implantation in the mitral valve position, we created a sewing cuff by placing a $4 \mathrm{~mm}$ PTEF graft wrapped around the Melody valve (Figure 1) and surgically implanted the valve in the pulmonary valve position using a continuous suturing technique. The valve was not dilated by a balloon and was left as a baseline diameter of $18 \mathrm{~mm}$. This technique is particularly attractive for a patient like this who is in rapid somatic growth. The valve can be dilated in future when the valve becomes small relatively to the rest of the heart.
Trezzi and colleagues ${ }^{3}$ should be congratulated for their innovative approach to overcome this difficult problem, and their follow-up study would be of great interest.

\section{References}

1. Morray BH, McEhinney DB, Boudiemline Y, Gewilling M, Kim DW, Bocks ML, et al. Multicenter experience evaluating transcatheter pulmonary valve replacement in bovine jugular vein (Contegra) right ventricle to pulmonary artery conduits. Circ Cardiovasc Interv. 2017;10:e004914.

2. Cheatham JP, Hellenbrand WE, Zahn EM, Jones TK, Berman DP, Vincent JA, et al. Clinical and hemodynamic outcome up to 7 years after transcatheter pulmonary valve replacement in the US melody valve investigational device exemption trial. Circulation. 2015;131:1960-70.

3. Trezzi M, Bandisode VM, Kavarana MN, Bradley SM. Surgical technique for placement of the Melody valve in a dilated right ventricular outflow tract. J Thorac Cardiovasc Surg. 2018;155:739-41.

4. Dos L, Dadashev A, Tanous D, Ferreira-González IJ, Haberer K, Siu SC, et al. Pulmonary valve replacement in repaired tetralogy of Fallot: determinants of early postoperative adverse outcomes. J Thorac Cardiovasc Surg. 2009;138:553-9.

5. Shinkawa T, Lu CK, Chipman C, Tang X, Gossett JM, Imamura M. The midterm outcomes of bioprosthetic pulmonary valve replacement in children. Semin Thorac Cardiovasc Surg. 2015;27:310-8. 